\title{
First-in-class Pan Caspase Inhibitor Developed for Liver Disease
}

Steven D. Linton,* Teresa Aja, Robert A. Armstrong, Xu Bai, Long-Shiuh Chen, Ning Chen, Brett Ching, Patricia Contreras, Jose-Luis Diaz, Craig D. Fisher, Lawrence C. Fritz, Patricia Gladstone, Todd Groessl, Xin Gu, Julia Herrmann, Brad P. Hirakawa, Niel C. Hoglen, Kathy G. Jahangiri, Vincent J. Kalish, Donald S. Karanewsky, Lalitha Kodandapani, Joseph Krebs, Jeff McQuiston, Steven P. Meduna, Kip Nalley, Edward D. Robinson, Robert O. Sayers, Kristen Sebring, Alfred P. Spada, Robert J. Ternansky, Kevin J. Tomaselli, Brett R. Ullman, Karen L. Valentino, Suzanne Weeks, David Winn, Joe C. Wu, Pauline Yeo, and Cheng-zhi Zhang.

Idun Pharmaceuticals, 9380 Judicial Drive, San Diego, CA 92121

slinton@idun.com

Supporting Information

Contents of SI: Contains experimental details for the synthesis and for the determination of biological activity, spectral data and elemental analysis. 


\section{ASSAY FOR INHIBITION OF CASPASE ACTIVITY}

\section{A. Determination of IC50 Values}

Fluorescence enzyme assays detecting the activity of the compounds utilizing the recombinant caspase enzymes are performed according to Thornberry et al. (Nature, 356:768-774 (1992)) and Nicholson et al. (Nature, 376:37-43 (1995)) respectively, (herein incorporated by reference) in 96 well microtiter plates. The substrate is Acetyl-Tyr-Val-Ala-Asp-amino-4-methylcoumarin (AMC) for the ICE assay and Acetyl-Asp-Glu-Val-Asp-amino-4-methylcoumarin for the csp-3, csp-6, csp-8 assays. Enzyme reactions are run in ICE buffer (25 mM HEPES, 1 mM EDTA, $0.1 \%$ CHAPS, $10 \%$ sucrose, $\mathrm{pH} 7.5$ ) containing $2 \mathrm{mM}$ DTT at room temperature in duplicate.

The assays are performed by mixing the following components:

- $\quad 50 \mu \mathrm{L}$ csp1, csp-3, csp-6, csp-8 $(18.8,0.153,38$, and $8.1 \mathrm{nM}$ concentrations, respectively) or csp-7 (1 unit) enzyme in ICE buffer containing either 8.0 (csp-1, csp-6, csp-3) or 20 (csp-8) mM DTT;

- $\quad 50 \mu \mathrm{L}$ compound of to be assayed or ICE buffer (control); and

- $100 \mu \mathrm{L}$ of $20[\mathrm{mu}] \mathrm{M}$ substrate.

The enzyme and the compound to be assayed are allowed to preincubate in the microtitre plate wells for 30 minutes at room temperature prior to the addition of substrate to initiate the reaction. Fluorescent AMC product formation is monitored for one hour at room temperature by measuring the fluorescence emission at $460 \mathrm{~nm}$ using an excitation wavelength of $360 \mathrm{~nm}$. The fluorescence change in duplicate (control) wells are averaged and the mean values are plotted as 
a function of inhibitor concentration to determine the inhibitor concentration producing $50 \%$ inhibition $\left(\mathrm{IC}_{50}\right)$.

B. Determination of the dissociation constant Ki and irreversible rate constant $\mathrm{k} 3$ for irreversible inhibitors

For the irreversible inhibition of a caspase enzyme with a competitive irreversible inhibitor; using the model represented by the following formulas:

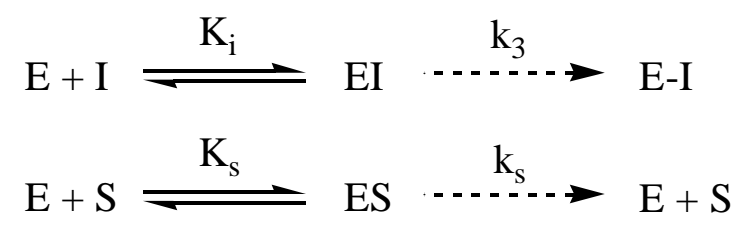

\section{Equation 1}

$\left.[P] t=[E]^{T}\left(\frac{[S] K_{i}}{[I] K_{s}}\right)\left(\frac{k_{s}}{k_{3}}\right)\left[1-e^{-k_{3} t /\left(1+\frac{K_{i}}{[I]}\right.}\left(1+\frac{[S]}{K_{s}}\right)\right)\right]$

The product formation at time t may be expressed as shown in equation 1, where E, I, EI and E-I denote the active enzyme, inhibitor, non-covalent enzyme-inhibitor complex and covalent enzyme-inhibitor adduct, respectively. The $\mathrm{K}_{\mathrm{i}}$ value is the overall dissociation constant of the reversible binding steps, and $\mathrm{k}_{3}$ is the irreversible rate constant. The $[\mathrm{S}]$ and Ks values are the substate concentration and dissociation constant of the substrate bound to the enzyme, respectively. $[\mathrm{E}]<\mathrm{T}>$ is the total enzyme concentration. The above equations are used to determine the $\mathrm{K}_{\mathrm{i}}$ and $\mathrm{k}_{3}$ values of a given inhibitor bound to a caspase. Thus, a continuous assay is run for sixty minutes at various concentrations of the 
inhibitor and the substrate. The assay is formulated as described above for generating the data in Tables $1 \& 2$, except that the reaction is initiated by adding the enzyme to the substrate-inhibitor mixture. The $\mathrm{K}_{\mathrm{i}}$ and $\mathrm{k}_{3}$ values are obtained by simulating the product AMC formation as a $\begin{array}{llllll}\text { function } & \text { of } & \text { time }\end{array}$

\section{ASSAY FOR INHIBITION OF ANTI-FAS INDUCED JURKAT CELL DEATH}

Assay Media: RPMI 1640/10\% FBS/100 units/ml Penicillin-G/100 $\mu \mathrm{g} / \mathrm{ml}$ Streptomycin.

Jurkat clone E6-1 cell line: The cell line Jurkat clone E6-1 is a human T cell leukemia suspension cell line. Cultures are maintained at a density less than 1x106 cells/ml by subculturing twice weekly to a density between 8x104 and 2x105 cells/ml in RPMI 1640 with $10 \% \mathrm{FBS}$ in a $37^{\circ} \mathrm{C} / 5 \% \mathrm{CO}_{2}$ incubator.

\section{PROCEDURE/METHODOLOGY:}

Cell Preparation: Jurkat clone E6-1 cells are plated at a density of 100,000 cells/well in fresh assay media in a flat-bottom tissue culture-treated Costar 96-well plate in a volume of $50 \mu 1 /$ well. The assay plates with cells are incubated at $37^{\circ} \mathrm{C} / 5 \% \mathrm{CO}_{2}$ over the course of the assay.

Compound Dilutions: Compounds are solubilized in DMSO at a concentration of $20 \mathrm{mM}$. The compounds are diluted with assay media prior to addition to the assay plates containing cells. Compounds are titrated to produce an eight-point dose response curve, ranging from $100 \mu \mathrm{M}$ to $0.032 \mu \mathrm{M}$ final concentration. Compounds are added to the 
assay plate in a volume of $25 \mu \mathrm{l}$ and incubated for 1 hour at $37^{\circ} \mathrm{C} / 5 \% \mathrm{CO}_{2}$ before the addition of anti-Fas.

Plate Setup: Each assay plate contains replicate wells which are not treated with anti-fas (untreated controls) and wells which do not contain a caspase inhibitor (death controls) in addition to three compound dose response curves. Control wells receive $25 \mu 1 /$ well assay media in lieu of compound dilution. In each set of assay plates a control compound (zVADfmk) is titrated with the test compounds.

Anti-fas Addition: Anti-fas (clone CH-11 obtained from PanVera, Corp.) is diluted to 425 $\mathrm{ng} / \mathrm{ml}$ with assay media and $10 \mu \mathrm{l} /$ well is added to the assay plate except the untreated controls which receive $10 \mu \mathrm{l} /$ well assay media. The final anti-fas concentration is 50 $\mathrm{ng} / \mathrm{ml}$. Assay plates are incubated for 24 hours at $37^{\circ} \mathrm{C} / 5 \% \mathrm{CO}_{2}$. 
Viability Evaluation: After 24 hours of exposure to anti-fas, cells are evaluated by inverted phase microscopy for anti-fas induced cell death inhibition, followed by a MTT viability assay. $10 \mu \mathrm{l} /$ well of a MTT stock solution in basal media is added to make a final MTT concentration in the assay plate of $0.5 \mathrm{mg} / \mathrm{ml}$. The assay plates are incubated at $37^{\circ} \mathrm{C} / 5 \% \mathrm{CO} 2$ for 1.5 hours. $100 \mathrm{ml} /$ well Extraction Buffer (10\% SDS, $2.5 \%$ Acetic Acid, and $2.5 \% 1 \mathrm{~N} \mathrm{HCl}$ in $50 \%$ dimethylformamide) is then added to the well. The assay plate is sealed. The formazan crystals are extracted at room temperature overnight. The assay plates are read on a spectrophotometer plate reader at an absorbance wavelength of $560 \mathrm{~nm}$. Background absorbance (measured at $650 \mathrm{~nm}$ ) is then subtracted.

Results: The resulting optical densities are evaluated relative to the controls. The untreated controls are established as $100 \%$ and the death control is set at $0 \%$. The average of the replicate well optical densities are converted to percent control and the dose response curve for each compound is evaluated for inhibition, consistency with the microscopic evaluation, and an $\mathrm{IC}_{50}$ value is generated.

\section{REFERENCES:}

Armstrong RC, Aja T, Xiang J, Gaur S, Krebs JF, Hoang K, Bai X, Korsmeyer SJ, Karanewsky DS, Fritz LC, Tomaselli KJ. Fas-induced activation of the cell death-related protease CPP32 is inhibited by Bcl-2 and by ICE family protease inhibitors. J Biol Chem 1996, 271, 16850-16855. 
Hansen MB, Nielsen SE, Berg K. Re-examination and further development of a precise and rapid dye method for measuring cell growth/cell kill. J Immunol Methods 1989, 199, 203210.

Mosmann T. Rapid colorimetric assay for cellular growth and survival: application to proliferation and cytotoxicity assays. J Immunol Methods 1983, 65, 55-63.

\section{ASSAY FOR DETERMINATION OF IL-1 $\beta$ SECRETION FROM LPS-STIMULATED THP-1 CELLS.}

THP-1 Cell Line: The cell line THP-1 is a human acute monocytic leukemia suspension cell line. Cultures are maintained in log-phase growth at a density less than $1 \times 106$ cells $/ \mathrm{ml}$ by subculturing twice weekly to a minimum density of $2.5 \times 105$ cells $/ \mathrm{ml}$ in culture media in a humidified $37^{\circ} \mathrm{C} / 5 \% \mathrm{CO}_{2}$ incubator.

Culture Media: RMPI 1640 with 20\% FBS, 2.5 g/l glucose, $1 \mathrm{mM}$ sodium pyruvate, 10 mM HEPES, and $50 \mu \mathrm{M}$ ß-mercaptoethanol.

Assay Media: RPMI 1640 with $2.5 \mathrm{~g} / \mathrm{l}$ glucose, $1 \mathrm{mM}$ sodium pyruvate, $10 \mathrm{mM}$ HEPES, and $50 \mu \mathrm{M} \beta$-mercaptoethanol. 
Cell Preparation:THP-1 cells are plated at a density of 150,000 cells/well in fresh culture media in a flat-bottom tissue culture treated Costar 96-well plate in a volume of 140 $\mu 1 /$ well. The assay plates are incubated in a humidified $37^{\circ} \mathrm{C} / 5 \% \mathrm{CO}_{2}$ environment.

Plate Setup: Each assay plate contains replicate wells which are not treated with interferon-gamma nor LPS (untreated controls) and wells which do not contain a caspase inhibitor, but are treated with interferon-gamma and LPS (death controls), in addition to five compound dose response curves in duplicate. Control wells received $20 \mu \mathrm{l} /$ well culture media in lieu of compound dilution. In each set of assay plates a control compound is titrated along with the test compounds and the $\mathrm{IC}_{50}$ value generated is compared with historical values for consistency.

Compound Dilutions: Compounds are dissolved in DMSO at a concentration of $20 \mathrm{mM}$. The compounds are diluted with culture media prior to addition to the assay plates containing cells. Compounds are titrated to produce an eight-point dose response curve at ten-fold the final concentration of $32 \mu \mathrm{M}$ to $0.01 \mu \mathrm{M}$. Compounds are added to the assay plate containing the THP- 1 cells in a volume of $20 \mu 1$ and incubated for 1 hour.

Interferon-gamma Addition: The stock of interferon-gamma is at a concentration of 100,000 units $/ \mathrm{ml}$ in $0.1 \% \mathrm{BSA} / 10 \mathrm{mM}$ acetic acid. This stock is diluted in culture media to 1000 units $/ \mathrm{ml}$, ten-fold the final concentration. Transfer $20 \mu \mathrm{l} /$ well of the 1000 units/ml interferon-gamma dilution for a final concentration of 100 units/ml, except to the 
untreated controls. Add $20 \mu \mathrm{l} /$ well culture media to the untreated controls. Incubate assay plates at $37^{\circ} \mathrm{C} / 5 \% \mathrm{CO}_{2}$ in a humidified incubator for 4 hours.

LPS Addition: The LPS stock solution is at a concentration of $1 \mathrm{mg} / \mathrm{ml}$ in DPBS. This stock is diluted in culture media to $100 \mu \mathrm{g} / \mathrm{ml}$, ten-fold the final concentration. Except to the untreated controls, $10 \mu \mathrm{l} /$ well of the $100 \mu \mathrm{g} / \mathrm{ml}$ LPS dilution is added for a final concentration of $10 \mu \mathrm{g} / \mathrm{ml}$. Add $20 \mu \mathrm{l} /$ well culture media to the untreated control. Assay plates are incubated overnight at $37^{\circ} \mathrm{C} / 5 \% \mathrm{CO}_{2}$ in a humidified incubator.

Quantitation of IL-1 $\beta$ Secretion: The amount of IL-1ß released by the THP-1 cells is determined using a commercially available kit from R\&D Systems. Supernates are harvested from the assay plate with a vacuum manifold and a filter plate. For the IL-1ß assay, the supernates are diluted 1:2 with assay media $(110 \mu \mathrm{l}$ supernate combined with $110 \mu 1$ assay media). Transfer $200 \mu 1 /$ well supernate dilution to the IL-1ß ELISA plate. At this point, the assay procedure for the Quantikine human IL-1ß immunoassay kit is followed closely.

After following the manufacturer's assay procedure closely, the resulting optical densities from the IL-1 $\beta$ ELISA are evaluated relative to the controls. The untreated controls are established as $100 \%$ Activity and the death control is set at $0 \%$ Activity. The average of the replicate well optical densities are converted to percent control, the dose response curve for each compound is evaluated for inhibition, and an $\mathrm{IC}_{50}$ value is generated. 


\section{REFERENCES:}

Tsuchiya S, Yamabe M, Yamaguchi Y, Kobayashi Y, Konno T, Tada K. Establishment and characterization of a human acute monocytic leukemia cell line (THP-1). Int J Cancer 1980; $26,171-176$.

Tsuchiya S, Kobayashi Y, Goto Y, Okumura H, Nakae S, Konno T, Tada K. Induction of maturation in cultured human monocytic leukemia cells by phorbol diester. Cancer Res 1982, 42, 1530-1536.

Weiss A, Wiskocil RL, Stobo JD. The role of T3 surface molecules in the activation of human T cells: a two stimulus requirement of IL-2 production reflects events occurring at a pre-translational level. J Immunol 1984; 133, 123-128.

\section{PROTOCOL FOR MURINE $\alpha$-FAS-INDUCED MODEL OF LIVER INJURY}

Materials:Anti-Fas antibody ( $\alpha$-Fas) was purchased from PharMingen (Jo-2: PharMingen, San Diego, CA). Pentobarbital (Nembutol) was purchased from Western Medical Supply (Arcadia, CA). Lipopolysaccharide was purchased from List Biologicals (E coli, 0111.B4; Campbell, CA). D-Galactosamine was purchased from Calbiochem (San Diego, CA). Microsomes and S9 fractions were obtained from In Vitro 
Technologies (Baltimore, MD). All other materials were purchased from Sigma Chemical Co., (St. Louis, MO) unless indicated specifically in the text.

Animals and Treatment: Male balb/c mice (Harlan Sprague-Dawley, Indianapolis, IN) weighing approximately 20-25 grams were used for the $\alpha$-Fas and D-Gln/LPS experiments. Male Sprague-Dawley rats weighing approximately $250 \mathrm{~g}$ (Harlan Sprague-Dawley, Indianapolis, IN) were used for the D-gln/LPS and pharmacokinetic studies. For the biliary excretion experiments, bile duct-cannulated rats were purchased (Harlan Sprague-Dawley, Indianapolis, IN). All animals were acclimated for at least 3 days prior to experimentation.

$\alpha$-Fas Model. $\alpha$-Fas prepared in saline was injected via tail vein, iv at a dose of 200 ug/kg. IDN-6556 was prepared in either saline (when administered as a sodium salt), 100 $\mathrm{mM}$ phosphate buffer $(\mathrm{pH}$ 7.4) or DMSO:water (1:1) and dosed immediately after administration of $\alpha$-Fas. Similar volumes of appropriate vehicle were administered to control animals. Preliminary experiments determined that the vehicles do not affect $\alpha$ Fas- or D-gln/LPS-mediated liver injury (data not shown). When comparing efficacy by multiple routes of administration, IDN-6556 was administered IP, PO, IM or IV (0.03 - 3 $\mathrm{mg} / \mathrm{kg}$ ) immediately after administration of $\alpha$-Fas antibody. Six hr after administration of $\alpha$-Fas, mice were anesthetized with pentobarbital (50 $\mathrm{mg} / \mathrm{kg}$, ip) and plasma was prepared from blood collected by cardiac puncture. In some experiments, livers were also harvested and immediately frozen for determination of caspase 3-like activity or formalin-fixed, embedded in paraffin and stained with hematoxylin and eosin for 
histological analysis. When IDN-6556 or saline was administered pre- or post-Fas, treatment times are indicated relative to $\alpha$-Fas. In the post-dose experiment, lethality was monitored in a separate group of mice over a seven-day period.

\section{REFERENCES:}

Ogasawara, J.; Watanabe-Fukunaga, R.; Adachi, M.; Matsuzawa, A.; Kasugai, T.; Kitamura, Y.; Itoh, N.; Suda, T.; Nagata, S. Lethal effect of the anti-Fas antibody in mice. Nature 1993, 364, 806-809.

\section{MEDICINAL CHEMISTRY ROUTE FOR THE PREPARATION OF IDN-6556}

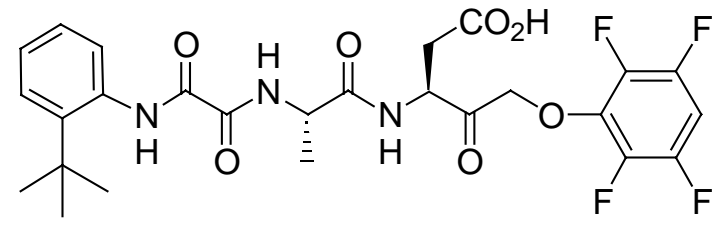

(3S)-3-[N-(N'-(2-TERT-BUTYLPHENYL)OXAMYL)ALANINYL] AMINO-5-(2',3',5',6'TETRAFLUOROPHENOXY)-4-OXOPENTANOIC ACID

General:

Unless otherwise noted, moisture sensitive reactions were conducted under dry nitrogen. Analytical thin-layer chromatography (TLC) was performed on pre-coated plates of silica gel 
$60 \mathrm{~F}_{254}$ (layer thickness $250 \mu \mathrm{M}$ ) from Merck. Preparative thin-layer chromatography was performed on 20x20cm precoated plates of silica gel $60(1000 \mu \mathrm{M})$ from Merck. Compounds were visualized by UV and/or with iodine and or $20 \%$ phosphomolybdic acid in ethanol. Flash chromatography was performed with silica gel 60 (70-230 mesh ASTM, Merck) with the solvent system indicated. ESI-MS spectra were recorded on a Micromass Quattro LCZ apparatus. ${ }^{1} \mathrm{H}$ NMR experiments were recorded on a Varian Gemini 2000 300MHz instrument. All samples were prepared as dilute solutions in either $\mathrm{CDCl}_{3}$ with $\mathrm{v} / \mathrm{v} 0.05 \%$ TMS or DMSO $\mathrm{d}_{6}$ with $\mathrm{v} / \mathrm{v}$ 0.05\% TMS. Chemical shifts are reported in parts per million ( $\mathrm{ppm}$ ) relative to tetramethylsilane (TMS), and spin multiplicities are given as s (singlet), br s (broad singlet), $\mathrm{d}$ (doublet), $\mathrm{t}$ (triplet), or $\mathrm{m}$ (multiplet). $\mathbf{J}$ values are reported as observed $\mathbf{J}$ values and are reported in hertz.

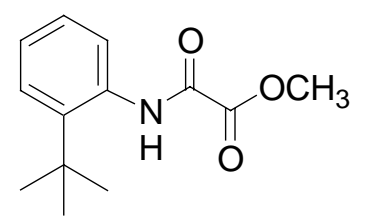

Part A: Methyl 2-[N-(2-tert-Butylphenylamino)]-2-oxoacetate A solution of 2-tert-butylaniline ( $57 \mathrm{~mL}, 54.5 \mathrm{~g}, 366 \mathrm{mmol})$, triethylamine $(56 \mathrm{~mL}, 402 \mathrm{mmol})$, and methylene chloride ( $370 \mathrm{~mL})$ was cooled to $0^{\circ} \mathrm{c}$ (ice bath) and stirred under nitrogen. An addition funnel was charged with methyl 2-chloro-2-oxoacetate $(50 \mathrm{~g}, 408 \mathrm{mmol}$ ) which was then added dropwise over 20 minutes to the stirred solution causing a significant exotherm. After addition complete, the resulting suspension was stirred for $1 \mathrm{hr}$. The suspension was then concentrated under vacuum, which is then taken up in ethyl acetate and partitioned with water. The aqueous layer was washed twice with ethyl acetate, and the combined organic layers were 
then extracted with $5 \%$ aqueous potassium bisulfate, followed by saturated sodium chloride, and then dried over magnesium sulfate and concentrated under reduced pressure. The resulting oil was then dried overnight, then recrystallized from 3:1 hexanes/toluene (two crops) to give the title compound as a white crystalline solid (60.43 g, $70 \%$ ). TLC (ethyl acetate-hexanes 3:7) $\mathrm{R}_{\mathrm{f}}=0.43 .{ }^{1} \mathrm{H} \mathrm{NMR}\left(\mathrm{CDCl}_{3} \mathrm{TMS}\right) \delta 9.20(\mathrm{br} \mathrm{s}, 1 \mathrm{H}), 7.97(\mathrm{dd}, 1 \mathrm{H}, \mathrm{J}=8.0, \mathrm{~J}=1.4), 7.43(\mathrm{dd}, 1 \mathrm{H}, \mathrm{J}$ $=7.8, \mathrm{~J}=1.5), 7.26-7.34(\mathrm{~m}, 1 \mathrm{H}), 7.16-7.22(\mathrm{~m}, 1 \mathrm{H}), 4.00(\mathrm{~s}, 3 \mathrm{H}), 1.46(\mathrm{~s}, 9 \mathrm{H}) \mathrm{ppm}$.

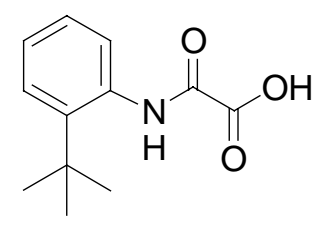

Part B: N-(2-tert-Butylphenylamino)oxamic acid

To a solution of methyl 2-[N-(2-tert-Butylphenylamino)]-2-oxoacetate (59.8 g, $254 \mathrm{mmol})$ in 1,4-dioxane $(600 \mathrm{~mL})$ was slowly added $1 \mathrm{~N}$ lithium hydroxide $(300 \mathrm{~mL}, 300 \mathrm{mmol})$. The solution was stirred for 1 hour. The solution was then acidified dropwise with concentrated $\mathrm{HCl}$ (12M, $25.0 \mathrm{~mL}, 300 \mathrm{mmol})$, and the resulting solution was extracted with ethyl acetate (3 times) and the combined organic extracts were then washed with saturated sodium chloride, dried over magnesium sulfate, and concentrated under vacuum and recrystallized from ethyl acetate/hexanes to yield the title compound (32.55 g, 58\%). TLC (5:4:1 methylene chloride/ethyl acetate/methanol) $\mathrm{R}_{\mathrm{f}}=0.25$. $\mathrm{MS}(\mathrm{ES})$ for $\mathrm{C}_{12} \mathrm{H}_{15} \mathrm{NO}_{3}$ (MW 221.25): negative 
$219.77(\mathrm{M}-\mathrm{H}) .{ }^{1} \mathrm{H}$ NMR $\left(\mathrm{CDCl}_{3} \mathrm{TMS}\right) \delta 9.34(\mathrm{br} \mathrm{s}, 1 \mathrm{H}), 7.91(\mathrm{dd}, 1 \mathrm{H}, \mathrm{J}=7.69, \mathrm{~J}=1.65), 7.45$

$(\mathrm{dd}, 1 \mathrm{H}, \mathrm{J}=7.69, \mathrm{~J}=1.65), 7.23-7.33(\mathrm{~m}, 2 \mathrm{H}), 4.46(\mathrm{vb} \mathrm{s}, 2 \mathrm{H}), 1.47(\mathrm{~s}, 9 \mathrm{H}) \mathrm{ppm}$.

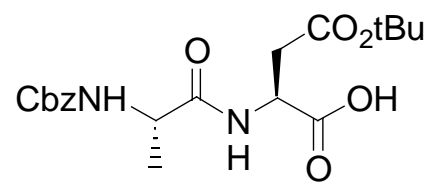

Part C: [(N-Benzyloxycarbonyl)Alaninyl]Aspartic Acid, [beta]-tert-Butyl Ester

To a suspension of aspartic acid $\beta$-tert-butyl ester $(3.784 \mathrm{~g}, 20 \mathrm{mmol})$ in dimethylformamide $(150 \mathrm{~mL})$ at room temperture under nitrogen was added bis(trimethylsilyl)-trifluoroacetamide (10.6 mL, $40 \mathrm{mmol}$ ). After stirring at room temperature for $30 \mathrm{~min}$, the resulting clear solution was treated with (N-benzyloxycarbonyl)alanine N-hydroxysuccinimide ester (6.406 g, 20 mmol). After stirring at room temperature for 18 hours, the mixture was treated with water $(20 \mathrm{~mL})$, stirred for 15 minutes and then partitioned between ethyl acetate \& water. The organic phase was washed with water, $5 \%$ potassium bisulfate and saturated sodium chloride solutions, dried over anhydrous sodium sulfate, and evaporated to dryness. The residue was then taken up in ethyl ether and extracted with saturated sodium bicarbonate. The aqueous extract was acidified $(\mathrm{pH}$ 2.0) with concentrated $\mathrm{HCl}$ and extracted with ethyl acetate. The ethyl acetate extract was washed with saturated sodium chloride solution, dried over anhydrous sodium sulfate and evaporated to a give the title compound $(6.463 \mathrm{~g}, 82 \%)$ as a white foam. TLC (ethyl acetatehexane-acetic acid); (70:30:2) $\mathrm{R}_{\mathrm{f}}=0.50$. MS(ES) for $\mathrm{C}_{19} \mathrm{H}_{26} \mathrm{~N}_{2} \mathrm{O}_{4}$ (MW 394.92): positive 395.20 $(\mathrm{M}+\mathrm{H})$; negative $393.06(\mathrm{M}-\mathrm{H}) .{ }^{1} \mathrm{H} \mathrm{NMR}\left(\mathrm{CDCl}_{3} \mathrm{TMS}\right) \delta 7.34(\mathrm{br} \mathrm{s}, 5 \mathrm{H}), 7.1(\mathrm{~d}, 1 \mathrm{H}, \mathrm{J}=), 6.36$ 
(br s, 1H), $5.53(\mathrm{~d}, 1 \mathrm{H} \mathrm{J}=)$, $5.1(\mathrm{~s}, 2 \mathrm{H}), 4.79-4.82(\mathrm{~m}, 1 \mathrm{H}), 4.27-4.32(\mathrm{~m}, 1 \mathrm{H}), 2.85(\mathrm{abx}, 2 \mathrm{H}, \mathrm{J}=$ 3.3, 5.1, 17.1, $64.8 \mathrm{~Hz}), 1.42(\mathrm{~s}, 9 \mathrm{H}), 1.406(\mathrm{t}, 3 \mathrm{H}, \mathrm{J}=7 \mathrm{~Hz}) \mathrm{ppm}$.<smiles>CCCCC(NC(=O)[C@H](C)NC(=O)[O-])C(=O)CBr</smiles>

Part D: (3S,4RS)-3-[(N-Benzyloxycarbonyl)Alaninyl]Amino-5-Bromo-4-Oxopentanoic Acid tert-Butyl Ester

A solution of $[(\mathrm{N}$-benzyloxycarbonyl)alaninyl $]$ aspartic acid, $\beta$-tert-butyl ester $(5.0 \mathrm{~g}, 12.7 \mathrm{mmol})$ and $\mathrm{N}$-methylmorpholine $(2.05 \mathrm{~g}, 2.23 \mathrm{~mL}, 20.3 \mathrm{mmol})$ in tetrahydrofuran $(65 \mathrm{~mL})$ at $-10^{\circ} \mathrm{C}$. ( $\mathrm{NaCl} / \mathrm{ice}$ bath) under nitrogen was treated dropwise with isobutyl chloroformate $(2.6 \mathrm{~g}, 2.47 \mathrm{~mL}, 19.04 \mathrm{mmol})$. After stirring at $-10^{\circ} \mathrm{C}$ for 20 minutes, the mixture was filtered (sintered glass) into a pre-cooled receiver (ice bath) washing the filter cake with additional tetrahydrofuran (approx. $48 \mathrm{~mL}$ ). The combined filtrate was treated with excess diazomethane/ethyl ether solution (prepared from $4.67 \mathrm{~g}, 31.73 \mathrm{mmol}$ of 1-methyl-3-nitro-1nitrosoguanidine, $34 \mathrm{~mL} 40 \% \mathrm{KOH} / 85 \mathrm{ml}$ ethyl ether) at $0^{\circ} \mathrm{C}$ (ice bath) under nitrogen. After stirring at $0^{\circ} \mathrm{C}$ for 15 minutes and at room temperature for 30 minutes, the reaction mixture was again cooled to $0^{\circ} \mathrm{C}$ and treated with $48 \% \mathrm{HBr}$ in acetic acid (34 mL, $\left.204 \mathrm{mmol}\right) /$ acetic acid (34 $\mathrm{mL}$ ). After stirring at $0^{\circ} \mathrm{C}$ for 15 minutes and at room temperature for 30 minutes, the mixture was partitioned between ethyl acetate $\&$ water. The organic phase was washed successively with water, saturated sodium bicarbonate, and saturated sodium chloride; dried over anhydrous 
sodium sulfate and evaporated to dryness and purified by flash chromatography on silica gel eluting with ethyl acetate-hexane (1:2) to give the title compound as a white foam (3.12 g, 52\%). TLC (ethyl acetate-hexane; 1:1) $\mathrm{R}_{\mathrm{f}}=0.70$. MS(ES) for $\mathrm{C}_{26} \mathrm{H}_{27} \mathrm{~N}_{2} \mathrm{O}_{6} \mathrm{Br}$ (MW 471.35): positive 472 $(\mathrm{M}+\mathrm{H})$; negative $470(\mathrm{M}-\mathrm{H}) .{ }^{1} \mathrm{H} \mathrm{NMR}\left(\mathrm{CDCl}_{3} \mathrm{TMS}\right) \delta 7.33(\mathrm{br} \mathrm{s}, 5 \mathrm{H}), 5.47-5.49(\mathrm{~m}, 1 \mathrm{H}), 5.1(\mathrm{~s}$, 2H), 4.89-4.95 (m, 1H), 4.25-4.29 (m, 1H), $4.1(\mathrm{~s}, 2 \mathrm{H}), 2.80(\mathrm{abx}, \mathrm{dd}, 2 \mathrm{H}, \mathrm{J}=17,4.8 \mathrm{~Hz}), 1.41$ $(\mathrm{s}, 9 \mathrm{H}), 1.40(\mathrm{t}, 3 \mathrm{H}, \mathrm{J}=9 \mathrm{~Hz}) \mathrm{ppm}$.

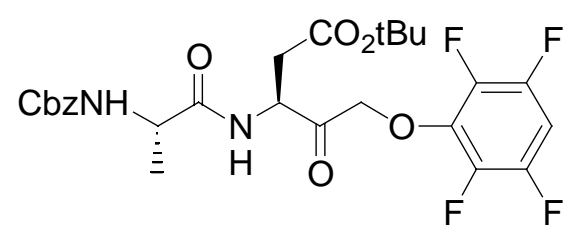

Part E: (3S,4RS)-3-[(N-Benzyloxycarbonyl)Alaninyl]Amino-5-(2',3',5',6'-Tetrafluorophenoxy)4-Oxopentanoic Acid tert-Butyl Ester

To a solution of (3S)-3-[(N-benzyloxycarbonyl)alaninyl]amino-5-bromo-4-oxopentanoic acid tert-butyl ester $(0.167 \mathrm{~g}, 0.355 \mathrm{mmol})$ and 2,3,5,6-tetrafluorophenol $(0.071 \mathrm{~g}, 0.426 \mathrm{mmol})$ in $\mathrm{N}, \mathrm{N}$-dimethylformamide $(2 \mathrm{~mL})$ at room temperature under nitrogen was added potassium fluoride $(0.082 \mathrm{~g}, 1.42 \mathrm{mmol})$. After stirring at room temperature for $4 \mathrm{hrs}$, the mixture was diluted with ethyl acetate, washed with saturated sodium bicarbonate and saturated sodium chloride solutions, dried over anhydrous sodium sulfate and evaporated to dryness. The crude material $(0.144 \mathrm{~g})$ was taken on to the next step without purification. TLC (ethyl acetate-hexane; 1:1) $\mathrm{R}_{\mathrm{f}}=0.60$. MS(ES) for $\mathrm{C}_{26} \mathrm{H}_{28} \mathrm{~F}_{4} \mathrm{~N}_{2} \mathrm{O}_{7}$ (MW 556.51): positive $557.16(\mathrm{M}+\mathrm{H})$; negative 555.03 (M-H). 


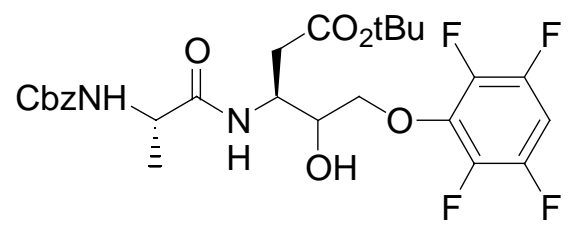

Part F: (3S,4RS)-3-[(N-Benzyloxycarbonyl)Alaninyl]Amino-5-(2',3',5',6'-Tetrafluorophenoxy)4-Hydroxypentanoic Acid tert-Butyl Ester

To a solution of crude (3S)-3-[(N-benzyloxycarbonyl)alaninyl]amino-5-(2',3',5',6'tetrafluorophenoxy)-4-oxopentanoic acid tert-butyl ester $(0.144 \mathrm{~g}, 0.26 \mathrm{mmol})$ in 1:1 methanol/tetrahydrofuran $(4 \mathrm{~mL})$ at $0^{\circ} \mathrm{C}$ under nitrogen was added sodium borohydride $(0.040 \mathrm{~g}$, $1.04 \mathrm{mmol}$ ). After stirring at $0^{\circ} \mathrm{C}$ for 1 hour, the mixture was concentrated and the residue partitioned between ethyl acetate-half saturated ammonium chloride solution (50\% saturated ammonium chloride/ 50\% water). The organic phase was washed with saturated sodium bicarbonate and saturated sodium chloride solutions, dried over anhydrous sodium sulfate and evaporated to dryness. The residue was purified by flash chromatography on silica gel eluting with ethyl acetate-hexanes (1:2) to give the title compound $(0.142 \mathrm{~g}, 78 \%)$ as a white foam. TLC (ethyl acetate-hexanes; 1:1) $\mathrm{R}_{\mathrm{f}}=0.50$. MS(ES) for $\mathrm{C}_{26} \mathrm{H}_{30} \mathrm{~F}_{4} \mathrm{~N}_{2} \mathrm{O}_{7}$ (MW 558.53): positive $559.20(\mathrm{M}+\mathrm{H})$; negative $557.07(\mathrm{M}-\mathrm{H}) .{ }^{1} \mathrm{H}$ NMR $\left(\mathrm{CDCl}_{3} \mathrm{TMS}\right) \delta 7.32(\mathrm{br} \mathrm{s}, 6 \mathrm{H}), 7.04-7.12(\mathrm{~m}$, 
1H), 6.72-6.83 (m, 1H), 5.44-5.48 (m, 1H), $5.08(\mathrm{~s}, 2 \mathrm{H}), 4.30-4.38(\mathrm{~m}, 1 \mathrm{H}), 4.14-4.28(\mathrm{~m}, 2 \mathrm{H})$, 4.12-4.03 (m, 1H), 2.56-2.67 (m, 2H), $1.43(\mathrm{~s}, 9 \mathrm{H}), 1.36(\mathrm{dd}, 3 \mathrm{H}, \mathrm{J}=7.1, \mathrm{~J}=2.9$ ) ppm.

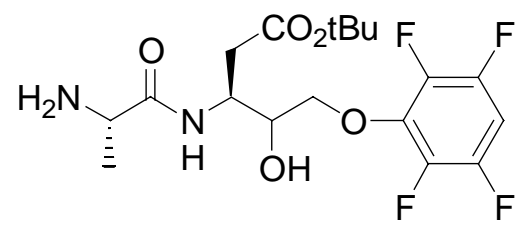

Part G: (3S,4RS)-3-(Alaninyl)Amino-5-(2',3',5',6'-Tetrafluorophenoxy)-4-Hydroxypentanoic Acid tert-Butyl Ester

To a solution of (3S, 4RS)-3-[(N-benzyloxycarbonyl)valinyl]amino-5-(2',3',5',6'tetrafluorophenoxy)-4-hydroxypentanoic acid tert-butyl ester $(0.112 \mathrm{~g}, 0.201 \mathrm{mmol})$ in methanol $(10 \mathrm{~mL})$ was added $10 \% \mathrm{Pd}-\mathrm{C}(0.017 \mathrm{~g})$ and resulting mixture stirred under a hydrogen atmosphere (1 atmosphere, balloon) for 2 hrs. The mixture was filtered through Celite, washing the filter cake with methanol. The combined filtrates evaporated to dryness to yield the crude title compound as a colorless, viscous oil $(0.066 \mathrm{~g}, 70 \%)$ which was taken on to the next step without purification. TLC (ethyl acetate-hexanes; 1:1) $\mathrm{R}_{\mathrm{f}}=0.05$. $\mathrm{MS}\left(\mathrm{ES}\right.$ ) for $\mathrm{C}_{18} \mathrm{H}_{24} \mathrm{~F}_{4} \mathrm{~N}_{2} \mathrm{O}_{5}$ (MW 424.39): positive $425.19(\mathrm{M}+\mathrm{H})$. 


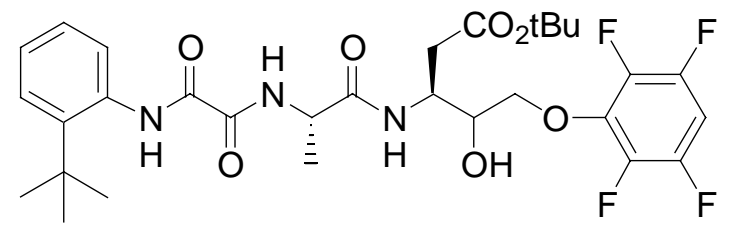

Part H: (3S,4RS)-3-[N-(N'-(2-tert-Butylphenyl)Oxamyl) Alaninyl]Amino-5-(2',3',5',6'Tetrafluorophenoxy)-4-Hydroxypentanoic Acid tert-Butyl Ester

To a solution of N-(2-tert-butylphenyl)oxamic acid $(0.041 \mathrm{~g}, 0.19 \mathrm{mmol})$ in methylene chloride $(6.0 \mathrm{~mL})$ at $0^{\circ} \mathrm{C}$ under nitrogen was added hydroxybenzotriazole hydrate $(0.030 \mathrm{~g}, 0.261 \mathrm{mmol})$ followed by addition of 1-ethyl-3-(3',3'-dimethyl-1'-aminopropyl)-carbodiimide hydrochloride (EDCI) $(0.050 \mathrm{~g}, 0.26 \mathrm{mmol})$. After stirring at $0^{\circ} \mathrm{C}$ for $10 \mathrm{~min}$, the mixture was treated with (3S,4RS)-3-(alaninyl)amino-5-(2',3',5',6'-tetrafluorophenoxy)-4-hydroxypentanoic acid tert-butyl ester $(0.079 \mathrm{~g}, 0.19 \mathrm{mmol})$ and $\mathrm{N}$-methylmorpholine (NMM) $(22 \mu \mathrm{L}, 0.20 \mathrm{mmol})$. After stirring at room temperature for $16 \mathrm{hrs}$, the mixture was partitioned between ethyl acetate \& water. The organic phase was washed with water, $5 \%$ potassium bisulfate, saturated sodium bicarbonate and saturated sodium chloride solutions, dried over anhydrous sodium sulfate and evaporated to give the crude title compound $(0.090 \mathrm{~g}, 77 \%)$ as a viscous oil. TLC (ethyl acetate-hexane; 1:1) $\mathrm{R}_{\mathrm{f}}=0.70$. MS(ES) for $\mathrm{C}_{30} \mathrm{H}_{37} \mathrm{~F}_{4} \mathrm{~N}_{3} \mathrm{O}_{7}$ (MW 627.63): positive $628.24(\mathrm{M}+\mathrm{H})$; negative 626.09 (MH). ${ }^{1} \mathrm{H}$ NMR $\left(\mathrm{CDCl}_{3} \mathrm{TMS}\right) \delta 9.2(\mathrm{~d}, 1 \mathrm{H}, \mathrm{J}=4.5 \mathrm{~Hz}) 8.07(\mathrm{br} \mathrm{d}, 1 \mathrm{H}), 7.96(\mathrm{~d}, 1 \mathrm{H}), 7.42(\mathrm{~d}, 1 \mathrm{H})$, 7.15-7.29 (m, 2H), 6.74-6.85 (m, 1H), 4.11-4.52 (m, 6H), 2.57-2.78 (m, 2H), 1.36-1.53 (m, 18H), $1.36-1.53(\mathrm{~m}, 18 \mathrm{H}) 1.18-1.28(\mathrm{~m}, 3 \mathrm{H}) \mathrm{ppm}$ 


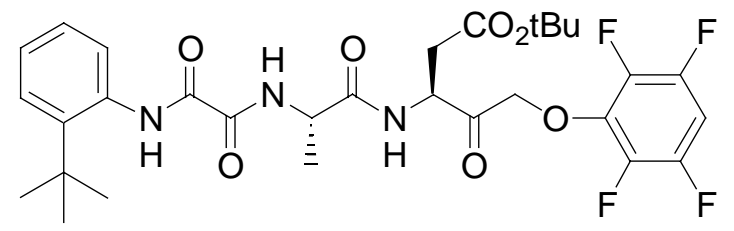

Part I: (3S)-3-[N-(N'-(2-tert-Butylphenyl)Oxamyl)Alaninyl]Amino-5-(2',3',5',6'-

Tetrafluorophenoxy)-4-Oxopentanoic Acid tert-Butyl Ester

To a solution of (3S,4RS)-3-[N-(N'-(2-tert-butylphenyl)oxamyl)alaninyl]amino-5-(2',3',5',6'tetrafluorophenoxy)-4-hydroxypentanoic acid tert-butyl ester $(0.0 .092 \mathrm{~g}$, ca $0.15 \mathrm{mmol})$ in methylene chloride $(6.5 \mathrm{~mL})$ at room temperature under nitrogen was added iodobenzene diacetate $(0.188 \mathrm{~g}, 0.58 \mathrm{mmol})$ followed by a catalytic amount of 2,2,6,6-tetramethyl-1piperidinyloxy free radical (TEMPO, $0.0046 \mathrm{~g}, 0.03 \mathrm{mmol}$ ). After stirring at room temperature for $16 \mathrm{hrs}$, the mixture was partitioned between ethyl acetate \& water. The organic phase was washed with saturated sodium bicarbonate and saturated sodium chloride solutions, dried over anhydrous sodium sulfate and evaporated to dryness. The residue $(0.096 \mathrm{~g})$ was purified by preparative layer chromatography on silica gel eluting with ethyl acetate-hexane (3:7) to give the title compound $(0.071 \mathrm{~g}, 77 \%)$ as a colorless glass. TLC (ethyl acetate-hexanes; 2:3) $\mathrm{R}_{\mathrm{f}}=0.60$. MS(ES) for $\mathrm{C}_{30} \mathrm{H}_{35} \mathrm{~F}_{4} \mathrm{~N}_{3} \mathrm{O}_{7}(\mathrm{MW} 625.61)$ : positive $626.21(\mathrm{M}+\mathrm{H})$; negative $624.06(\mathrm{M}-\mathrm{H})$. ${ }^{1} \mathrm{H}$ NMR (CDCl 3 , TMS) $\delta 9.52$ (br s, 1H), 7.96-8.03 (m, 2H), 7.41-7.44 (m, 1H), 7.25-7.30 (m, 1H), 
7.13-7.20 (m, 2H), 6.73-6.84 (m, 1H), 4.90-5.20 (m, 3H), 4.47-4.55 (m, 1H), 2.89 (abx, dd, 2H, J $=17,4.9 \mathrm{~Hz}), 1.56(\mathrm{~d}, 3 \mathrm{H}, \mathrm{J}=7.14 \mathrm{~Hz}), 1.46(\mathrm{~s}, 9 \mathrm{H}), 1.40(\mathrm{~s}, 9 \mathrm{H}) \mathrm{ppm}$.

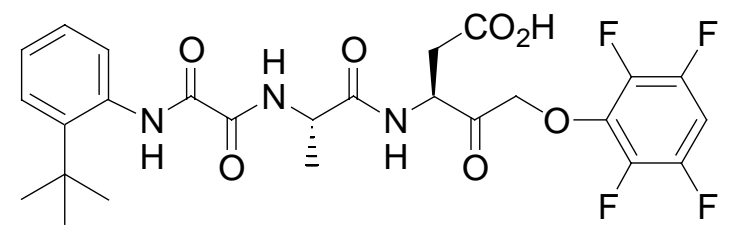

Part J: (3S)-3-[N-(N'-(2-tert-Butylphenyl)Oxamyl)Alaninyl]Amino-5-(2',3',5',6'Tetrafluorophenoxy)-4-Oxopentanoic Acid

To a solution of (3S)-3-[N-(N'-(2-tert-butylphenyl)oxamyl)alaninyl]amino-5-(2',3',5',6'tetrafluorophenoxy)-4-oxopentanoic acid, tert-butyl ester $(0.071 \mathrm{~g}, 0.11 \mathrm{mmol})$ and anisole $(0.05$ $\mathrm{mL})$ in methylene chloride $(2.5 \mathrm{~mL})$ at room temperature under nitrogen was added trifluoroacetic acid $(1.5 \mathrm{~mL})$. The resulting clear solution was stirred at room temperature for 1 hr, evaporated to dryness and chased with toluene-methylene chloride (1:1). The residue (0.061 g) was purified by preparative layer chromatography on silica gel eluting with methanolmethylene chloride (1:9) to give the title compound $(0.044 \mathrm{~g}, 69 \%)$ as a colorless glass. MS(ES) for $\mathrm{C}_{26} \mathrm{H}_{27} \mathrm{~F}_{4} \mathrm{~N}_{3} \mathrm{O}_{7}$ (MW 569.51): positive 592(M+Na); negative 568(M-H). Elemental analysis, calculated: C, 54.83; H, 4.78; N, 7.38; F, 13.34. Found: 54.68; H, 4.80; N, 7.30; F, $13.62 .{ }^{1} \mathrm{H}$ NMR (DMSO-d ${ }_{6}$, TMS) $\delta 9.93($ br s, 1H), 8.99-9.03 (m, 1H), 8.63-8.68 (m, 1H), 7.42-7.63 (m, 
3H), 7.19-7.30 (m, 2H), 5.16-5.31 (m, 2H), 4.60-4.66 (m, 1H), 4.29-4.40 (m, 1H), 3.20-3.64 (vb s, 1H), 2.68 (abx, dd, 2H, J = 16.7, $6.3 \mathrm{~Hz}), 1.56$ (d, 3H, J=7.14 Hz), 1.34 (m, 12H) ppm. 